ISSN No. 0974-035X

An indexed refereed \& peer-reviewed journal of higher education

Towards Excellence

UGC-HUMAN RESOURCE DEVELOPMENT CENTRE

Gujarat University, Ahmedabad-380009, Gujarat, India

\title{
A QUESTION OF RECOGNITION AND REDISTRIBUTION: UNDERSTANDING DOM AND MUSAHAR CASTES OF BIHAR
}

\author{
Dr. Amrita Shilpi
}

\begin{abstract}
The paper attempts to look into the issues of marginalisation and exclusion of Dom and Musahar castes of Bihar from the perspective of recognition and redistribution as argued by political theorist Nancy Fraser. She explains that a theory of social justice must be constructed and articulated in a way in which redistribution and recognition play equal and interwoven parts. Issues of marginalisation and exclusion of Dom and Musahar castes are discussed here as denial of recognition for these groups that have been subordinated for centuries by the caste structures, and, as disparities in redistribution, that has resulted in gross inequality of opportunities, wealth and income. Non-recognition/misrecognition and mal-distribution are the typical experience of Dom and Musahar that are marginalized and excluded. The data and discussion of this paper is based on the research entitled "Social Psychology of Marginalisation and Exclusion: A Study of Dom and Musahar Communities of Bihar" (2016-18)
\end{abstract}

Keywords: Recognition, Redistribution, Marginalization, Exclusion, Dom, Musahar

\section{Introduction}

"I conceive that there are two kinds of inequality among the human species; one, which I call natural or physical, because it is established by nature, and consists in a difference of age, health, bodily strength, and the qualities of the mind or of the soul: and another, which may be called moral or political inequality, because it depends on a kind of convention, and is established, or at least authorised by the consent of men. This latter consists of the different privileges, which some men enjoy to the prejudice of others; such as that of being more rich, more honoured, more powerful or even in a position to exact obedience." (Rousseau) 
Towards Excellence: An Indexed, Refereed \& Peer Reviewed Journal of Higher Education / Dr. Amrita Shilpi/ Page 13-35

We live in a society where plurality of conventions, difference of privileges and honor, and disparity of economic conditions are too glaring to be ignored. The solutions to such social problems are never single dimensional. Social scientists have incessantly been working on finding answers and correcting the ambiguities. One such attempt has been made by political theorist Nancy Fraser who expounds that a theory of social justice must be constructed and articulated in a way in which redistribution and recognition play equal and interwoven parts Garrett (2010). Fraser asserts that the injustices that confront individuals and groups are rooted in economy and culture. Arguing further she states that social justice encompasses two analytically distinct dimensions: a dimension of recognition that is related to the effects of institutionalized meanings and norms on the comparative status of social actors; and a dimension of distribution that is concerned with the allocation of disposable resources to social actors Fraser (2000). Whereas, lack of 'recognition' arises from detrimental socio-cultural representations, that is, from the 'othering' of a certain group; lack of the material resources results from maldistribution, in which equal participation of such groups is questionable because these groups lack the necessary resources to interact with others at par. In such cases, mal-distribution becomes a hindrance to uniformity of participation in social life thus resulting into social subordination and injustice.

Based on the above idea, the paper attempts to look into the issues of marginalisation and exclusion of Dom and Musahar castes of Bihar from the perspective of recognition and redistribution. It is an attempt to empirically analyze different sources of collective suffering from the perspective of Fraser. Only one dimension cannot explain the entire problem. Issues of marginalisation and exclusion of Dom and Musahar castes are discussed here as denial of recognition for these groups that have been subordinated for centuries by the caste structures, and, as disparities in redistribution, that has resulted in gross inequality of opportunities, wealth and income. Non-recognition, misrecognition and disrespect are the typical experience of Dom and Musahar that are marginalized and excluded. The data and discussion of this paper is based on the research entitled "Social Psychology of Marginalisation and Exclusion: A Study of Dom and Musahar Communities of Bihar" (2016-18).

\section{Objectives}

Literature and various studies show that individuals belonging to Dom and Musahar caste have poor control over their lives (Crook 1975; Briggs 1953; Fuchs 1981; Mukul 1999). Belonging to 
Towards Excellence: An Indexed, Refereed \& Peer Reviewed Journal of Higher Education / Dr. Amrita Shilpi/ Page 13-35

extremely backward scheduled caste community, there are hardly enough resources available to them (Tilak 1980; Deshpande 2000; Thorat and Newman 2009; Johdka, et al.2002). Their presence itself is stigmatized and they have been at the receiving end of negative public attitudes even within the scheduled castes (Ghurye 1957; Mishra 2007; Singh 2016; Philipose 2013. There have been extremely limited opportunities available to them to make social contributions (Clarke 1903; Kumari 2018). A vicious circle of discrimination has prevented them from participating in local life, which has led to further isolation. The question is, why? As stated above, the paper attempts to rework and understand social perception of marginalisation and exclusion of Dom and Musahar communities as two distinct but inter-related dimensions of recognition and redistribution as theorized by Nancy Fraser. The politics of redistribution is related to 'class politics', while the politics of recognition is understood as 'identity politics'(Ruth 2004). Fraser contrasts the two paradigms of redistribution and recognition in four areas: conception of injustice, cure for injustice, conceptions of the collectivities that suffer injustice and understandings of group differences (Fraser 1996). Based on this, the objectives of the paper are as follows:

The marginalisation and exclusion of Dom and Musahar communities is socio-economic (ingrained in the economic structure of society) but is also rooted in cultural, social patterns of representation, interpretation, and communication for e.g. cultural domination, non-recognition and disrespect.

The second objective is that, alleviation for marginalisation and exclusion is economic restructuring or redistribution ( which can be redistributing income and/or wealth, reorganizing the division of labour, changing the structure of property ownership, democratizing the procedures by which investment decisions are made, or transforming other basic economic structures) along with a cultural or symbolic change (which would involve 'transforming wholesale societal patterns of representation, interpretation, and communication' in ways that would change everyone's social identity).

The paper would also empirically ascertain whether Dom and Musahar communities are defined economically by a distinctive relation to the market or the means of production (for e.g. 'the exploited working class', 'low-paid menial labourers', or 'unwaged labour', who are disadvantaged in employment) and also the relations of recognition, for e.g. 'the low-status ethnic group' having lesser respect, esteem, and prestige. 
Towards Excellence: An Indexed, Refereed \& Peer Reviewed Journal of Higher Education / Dr. Amrita Shilpi/ Page 13-35

The fourth objective is understandings of group differences Is it due to socially constructed results of an unjust political economy or pre-existing cultural variations that has transformed into a value hierarchy.

\section{Methodology}

Out of the 38 districts of Bihar 5 districts were selected randomly for the conduct of the study. These districts were Muzaffarpur, Samastipur, Patna, Buxar and Purnea. Out of the 5 districts a total number of 635 persons, following incidental random sampling procedure, constituted sample of the study. Of the 635 subjects 196 were Dom and remaining 439 were Musahar. Both the communities Dom and Musahar were mostly living in rural areas of Bihar, therefore, the sample, by and large, constituted of rural population. In each district the population of Dom was very thin and they lived in the outskirts of the village. In a number of villages, Dom community was totally absent. Locating residential areas of Dom, this way, turned out to be quite challenging. One good thing was that they were available at home during day time making different items of bamboo. In contrast, Musahar were almost away during day time for labour work at different locations of the village. Musahar and Dom houses were mostly at one cluster in the village forming a mohalla called 'musahar/Dom tola' (hamlet). Musahar were contacted mostly at their place of work.

\section{Results}

Result of 14 statements from the interview schedule has been discussed in this section to understand the perception of marginalisation and exclusion of Dom and Musahar communities. An attempt has been made to see the felt impact of marginalization, exclusion on both the castes separately on the relevant statements of the interview schedule. Counting of respondents showing marginalisationor otherwise were performed and the significance of difference has been seen using chi square test of independence. Statement-wise chi-square analysis of the data obtained on both the castes Dom and Musahar separately has been presented in tables below.

\section{Earning opportunities provided by Panchayat}

\section{TABLE - 1}

A look into Table-1 reveals that on this statement majority showed no marginalisationin both the castes Dom and Musahar, the number being 171 for no marginalisation and 25 for marginalisationin Dom with per centages 87.2 and 12.8 and 428 for no marginalisation and 11 
Towards Excellence: An Indexed, Refereed \& Peer Reviewed Journal of Higher Education / Dr. Amrita Shilpi/ Page 13-35

for marginalization, in Musahar per centages being 97.5 and 2.5. This difference was further put to chi square test of independence with 50per cent probability to see the significance level. Chi square value in case of Dom came to be 108.755 and in Musahar 396.103 which were significant at or beyond 1 per cent level of confidence with $1 \mathrm{df}$.

In case of earning opportunities provided by Panchayats both the castes Dom and Musahar did not have a feeling of marginalisation and exclusion and the difference in number was significant. The respondents acknowledged that such works provided them a chance to work in nearby places and stay with their family.

\section{Fair chances of opportunity of work in comparison to others in Panchayat TABLE -2}

Table 2 provides response on the follow up question the opportunity provided to their caste members. Majority of respondents of Dom castes were self- employed and a very few were in government or private job. Musahars, in large number, worked as labourers and only a few worked in either government or private sectors.

As is evident, Dom respondents 171 (87.2per cent) showed marginalisation and 25(12.8per cent) did not respond to it. They informed of their inability to hard manual labour. They could weave baskets but such works were not provided by the panchayat. This statement was related to the first statement where the same number had shown no marginalisationwhile showing interest in job opportunities provided by the Panchayat. The group of 25 persons showing no interest/participation in statement 1 did not respond to the statement number 2. Since variable was constant, therefore, chi-square test could not be computed.

In case of Musahar respondents 35(8.0per cent) indicated "no marginalization" and 401 (91.3per cent) showed "marginalization" and remaining 3(0.7per cent) did not indicate any opinion. This difference was significant at or beyond 1per cent level of confidence with obtained chi-square value of 307.239 at $1 \mathrm{df}$. It might, however, be noted that in both the castes marginalisationwas seen in assigning opportunities by Panchayat, the per centages in Dom 87.2per cent and Musahar 91.3per cent, and majority stated that less opportunities were available to them in comparison to others, in both the castes.

\section{Information about Government schemes}

\section{TABLE- 3}


Towards Excellence: An Indexed, Refereed \& Peer Reviewed Journal of Higher Education / Dr. Amrita Shilpi/ Page 13-35

It would be evident from Table-3 that responses showing marginalisationis much higher than the responses of no marginalisationin both the castes of Dom and Musahar. No marginalisationresponses in Dom was only 6 (3.1per cent) and Musahar 51 (11.6per cent) as compared to marginalisationresponses in Dom 190 (96.9per cent) and Musahar 388 (88.4per cent). The difference in frequency of marginalisation and no marginalisationin both the groups Dom \& Musahar was significant at or beyond 1per cent level of confidence, the chi square value in case of Dom being 172.735 and Musahar 258.699 with $1 \mathrm{df}$.

Participation of local communities in public services is instrumental in achieving better development outcomes. Limited social interaction with members of the locality puts these groups at disadvantage. For want of relevant information they remain incapable to take advantage of the schemes in time. Several studies have shown that citizens do not participate actively, either because these services are not on high priority on or because they are uncertain about their participation making a difference. To overcome this impediment activists and policymakers have emphasized information, advocacy and awareness campaigns at the community level, as a way of encouraging people to participate more (Jenkins and Goetz 1999; Goetz and Jenkins 2001; Paul 2002). Proper mechanism needed to be envisaged so that such schemes be intimated to them timely to enable them to take advantage.

\section{Government subsidy for house construction}

\section{TABLE- 4}

A look into Table -4 indicates that majority of Dom had shown marginalisationby giving a 'no' response, the number being 145(74per cent) with 51(26per cent) showing 'no marginalization' indicating "yes response". In case of Musahar 296 (67.4per cent) showed marginalisationwhereas 143(32.6per cent) showed 'no marginalization'. The difference obtained in frequency of both the castes Dom and Musahar were put to chi-square test of significance to see if the difference was genuine one and had not come due to chance factor. In both the castes under investigation the chi-square value came to be significant, in case of Dom it was 45.082 and in Musahar 53.323 both significant at or beyond 1per cent level of confidence with $1 \mathrm{df}$.

It revealed that both the castes were not satisfied with Government subsidy for building houses. Marginalisationin both the castes was evident so far as this statement was concerned. Families of both the castes were seen living in thatched houses mostly and only a small number had 'pakka' houses. In the absence of Government subsidy they were not able to build a pakka house 
Towards Excellence: An Indexed, Refereed \& Peer Reviewed Journal of Higher Education / Dr. Amrita Shilpi/ Page 13-35

with minimum resources available with them. Dom caste had higher number of persons showing marginalization, 74 per cent as compared to Musahar caste, 67.4 per cent.

\section{Government subsidy for business}

\section{TABLE-5}

A look into Table-5 reveals that marginalisationresponses were high in both the castes as compared to no marginalisationresponse. In case of Dom only 2(1per cent) respondents showed no marginalisation and remaining 194(99per cent) showed marginalisationresponse. Similarly Musahar expressed 16(3.6per cent) no marginalisationresponse and 423(96.4per cent) marginalisationresponse. This difference in frequency was significant in both the cases, value of chi square in Dom being 188.082 and in Musahar 377.333 with 1 df.

Majority of both the castes showed discrimination in intimating welfare schemes meant for them by relevant agencies. They are so engrossed in their basic fight for survival, that it is almost impossible for them to even contemplate questioning administrative and political authorities to procure necessary information. These two caste people mostly were not well educated so unable to get information at right time from right place.

\section{Children going to school}

\section{TABLE -6}

Table-6 conveys that in both the castes Dom and Musahar had less marginalisationas their children did go to school in large cases. Dom had only 73 cases showing marginalisationconstituting 37.2per cent and Musahar 73 cases (16.6per cent). Of the 196 cases in Dom 123(62.8per cent) did not show marginalisation and of the 439 cases of Musahar 366 (83.4per cent) cases did not show marginalization. Difference in number showing marginalisationor otherwise was significant in both the castes, chi square value in Dom being 12.755 and in Musahar 195.556 with $1 \mathrm{df}$ in both the cases. The significance level in both the cases was 1per cent.This indicated that the difference in number did not come due to chance factor and was genuine one.

Having a school in the vicinity and majority of children going to showed a good sign of development. But an interesting observation was that the school belonged to mahadalit tola and no child from upper castes or even the other backward casted was enrolled in the school. On further enquiry it was revealed that government efforts, in form of various types of incentives 
Towards Excellence: An Indexed, Refereed \& Peer Reviewed Journal of Higher Education / Dr. Amrita Shilpi/ Page 13-35

for joining schools such as school dress, bags, books, other stationary items and scholarship etc were appreciated by the members of the Dom and Musahar castes.

Effect of marginalisation and exclusion was not seen on this count in majority of the cases. A small number, however, could not send their children to school as seniors of the family kept them engaged in some type of work for earnings and/or some other family support. Further effort was required to educate the elders of the family showing importance of education for better living and family support.

\section{Treatment in mid-day meal in schools}

\section{TABLE -7}

Table-7 informs that of the 196 (100per cent) Dom only135 (68.9 per cent) responded either one way or the other of marginalisation and 61(31.1per cent) did not respond. Out of 135 responses of Dom 76 (38.8per cent) showed no marginalisation and 59(30.1per cent) showed marginalization.

Similarly in case of Musahar, of the 439(100per cent) only 406(92.5per cent) responded on this issue. Out of 406 Musahar 287(65.4per cent) showed no marginalisation and 119(27.1per cent) showed marginalization. In Dom caste 61(31.1per cent) and in Musahar 33(7.5per cent) did not give answer to this statement. This way, the analysis was based on 135 and 406 cases of Dom and Musahar respectively. It is further evident that obtained value of chi square 2.141 did not reach 5per cent level of significance with $1 \mathrm{df}$. This meant the difference in frequency showing marginalisation and no marginalisation59 and 76 came due to chance factor.

Trend of marginalisationin case of Dom was not evident. In case of Musahar as well marginalisation was not evident, as people responding no marginalisation was higher as compared to marginalization, the numbers being 287 (65.4per cent) and 119 (27.1per cent), respectively. This difference was significant at or beyond 1per cent level of confidence, the chi square value being 69.517 with $1 \mathrm{df}$. This way, in both the castes marginalisation and exclusion were not evident as far as treatment in mid-day meal in schools was concerned.

One of the reasons for such response could be that the school was meant for the mahadalit tola and there was no mixing of other/ upper caste children with children of these castes.

\section{Availability of Utensil for mid- day meal provided by the school}


Towards Excellence: An Indexed, Refereed \& Peer Reviewed Journal of Higher Education / Dr. Amrita Shilpi/ Page 13-35

TABLE- 8

A look into Table-8 reveals that of the 196 (100per cent) Dom only 135(68.9per cent) responded to this statement. Dom had shown higher responses leading to marginalisationin comparison to no-marginalisationresponse, the member being 90(45.9per cent) and 45(23per cent) respectively. This difference was significant at or beyond 1 per cent level of confidence, the value of chi square being 15.00 significant at or beyond 1 per cent level of confidence with $1 \mathrm{df}$.

Some respondents of Dom community reported that they were asked to bring utensils for midday meal in schools from their houses. Responses on this statement were not provided by 61 persons (31.1per cent) as they were uncertain on correct response. This way, distribution was based on only 135 responses. In case of Musahar also 33 persons (7.5per cent) did not provide answer of the total sample so distribution was based on only 406 (92.5per cent) responses. In case of Musahar caste marginalisationresponses amounted to $185(42.1$ per cent) whereas no marginalisationresponses were of 221 (50.3per cent). This difference was, however, not significant at or beyond 5 per cent level of confidence with $1 \mathrm{df}$. This difference in responses came due to chance factor.

It further revealed that discrimination was prevalent in Dom caste but in case of Musahar it appeared to be less to some degree. A number of studies and literature has revealed that of the two castes in Mahadalit category, Dom had been on the receiving end of untouchability, for a long time but in case of Musahar it was not that intense even in the past as well. Dom respondents revealed that this trend was still prevalent, though in subtle ways. The Constitution of India makes Untouchability a punishable offense. Yet this social practice has been existing in clandestine manner. Change in attitude of people of others castes was needed to get a better and quick result. Marginalisation and exclusion on this aspect of life were quite evident in case of Dom caste but in case of Musahar it was not apparent as no marginalisationresponses were high as compared to marginalisationone.

\section{Getting tea on nearby tea shop in shop's glass/cup}

\section{TABLE-9}

It would be clear from Table-9 that on this statement responses of the subjects showed no marginalisationeffect both in case of Dom and Musahar . In case of Dom 163(83.2per cent) and Musahar 418(95.2per cent) showed no marginalisationwhere as in Dom and Musahar 33(16.8per cent) and 21(4.8per cent) showed marginalisationrespectively. The difference in frequency of 
Towards Excellence: An Indexed, Refereed \& Peer Reviewed Journal of Higher Education / Dr. Amrita Shilpi/ Page 13-35

both Dom \& Musahar was genuine and did not come due to chance factor as the chi square value of 86.224 and 359.018 were significant at or beyond 1per cent level of confidence with 1 df. Indication of social acceptability was an interesting observation here. A possible explanation could be that 'social' here is actually a market in which the conception of social positions and the normative features attached to them are conceptualized as the exchange of commodities. ${ }^{1}$

\section{Practice of untouchability}

\section{TABLE- 10}

The Constitution of India makes Untouchability a punishable offense. In an answer to the question on the topic, Table-10 indicates that responses on marginalisationwere high in case of Dom and less in case of Musahar. In Dom category no marginalisationresponses were 87(44.4per cent) and marginalisationresponses were 109 (55.6per cent) but the difference was not significant as the chi square value was 2.469 at $1 \mathrm{df}$. This difference, therefore, had come due to chance factor and not genuine one. In Musahar 'no marginalization' responses were 242(55.1per cent) and 'marginalization' 197(44.9per cent) and this difference was significant at or beyond 5per cent level of confidence, chi square value being 4.613 with $1 \mathrm{df}$. The age old practices of Untouchability, more or less, were not prevalent in society, as reposted. More numbers of both the castes Dom and Musahar denied untouchability with significant difference in Musahar and a trend in Dom.

But the way of life, such as habitation in clusters (tolas), different parts of river banks for performing rituals allotted to different castes, schools, handpumps specifically designated to those hamlets etc gave an impression that recognition and identification of groups were more of measures to keep them separate from mixing.

\section{Availability of hospital in vicinity for medical emergency}

\section{TABLE- 11}

Table-11 would make it clear that in case of Dom 'no marginalization' response was high as compared to marginalisationresponse, the numbers being 120 (61.2per cent) and 76(38.8per cent), respectively. This difference was significant at or beyond 5per cent level of confidence, chi square value being 9.878, with df 1 The difference was genuine one. Dom reported such an arrangement in nearby locality.

\footnotetext{
${ }^{1}$ Jean-Philippe Deranty. Conceptualising Social Inequality: Redistribution or Recognition?Social Inequality Today, Macquarie University, 12 November 2003 Department of Philosophy, Macquarie University
} 
Towards Excellence: An Indexed, Refereed \& Peer Reviewed Journal of Higher Education / Dr. Amrita Shilpi/ Page 13-35

Musahar, on the other hand, had different nature of response with marginalization, more in number, as compared to no marginalization, the number being 296(67.4per cent) and 143 (32.6per cent) respectively in both the categories of responses.

Here perception appeared to have a role in responses of the subjects. Distance might be the same of such facilities from a particular place but it was perceived in different ways sometimes based on level of aspiration and level of attainment. Dom had comparatively lower level of aspiration in comparison to Musahar community, therefore, considered the distance of hospital nearby showing no marginalization. Being socially placed slightly high in mahadalit group Musahar had high anticipation, so this difference perhaps.

\section{Hesitation in touching body by medics while administering treatment}

\section{TABLE- 12}

No marginalisationwas evident in Table-12 where both Dom and Musahar had shown high responses, number being 192(98per cent) and 397(90.4per cent). These numbers were significantly different from the marginalisationresponses of Dom and Musahar, number being $4(2$ per cent) and 42(9.6per cent) respectively. The chi square value in Dom and Musahar were 180.327 and 287.073, significant at 1per cent level of confidence with $1 \mathrm{df}$. 98per cent of Dom and 90.4per cent of Musahar showed no marginalisationas against 2per cent and 9.6per cent responses of marginalisationrespectively.

\section{Social status in the village}

\section{TABLE- 13}

It would be clear from Table-13 that both the castes Dom and Musahar felt marginalization, number being 173(88.3per cent) and 393(89.5per cent) respectively. No marginalisationresponses in Dom \& Musahar were only 23(11.7per cent) and 46(10.5per cent). The numbers in both the castes were significantly different, chi square values being 114.796 and 274.280 in Dom and Musahar respectively. The chi square values were significant at or beyond 1 per cent level of confidence with $1 \mathrm{df}$ each.

The responses were genuine which indicated that these two castes were not given equal status by upper caste people like them in society. A very small number, however, did not feel marginalisationon this count.

\section{Untouchability been eradicated from society}


Towards Excellence: An Indexed, Refereed \& Peer Reviewed Journal of Higher Education / Dr. Amrita Shilpi/ Page 13-35

\section{TABLE- 14}

Table14 shows that in case of Dom caste marginalisationwas evident as of the 196 persons 114 responded in favour of marginalisation and 82 did not show marginalization, the per centages being 58.2 for marginalisation and 41.8 for no- marginalization. In case of Musahar caste both the types of responses had almost the same number, 221 for marginalisation and 218 for no marginalization, per centages being 50.3 and 49.7 respectively.

The chi square value of 5.224 in case of Dom caste was significant at or beyond 5per cent level of confidence with $1 \mathrm{df}$. This showed that the outcome was genuine and had not come due to chance factor. Chi square value of Musahar .021 was not significant at 5per cent level of confidence with $1 \mathrm{df}$ showing that the difference in number of responses had come due to chance factor. So far as eradication of untouchability was concerned Dom caste felt that it had not been eradicated so far and Musahar caste felt otherwise.

An overall analysis of marginalisation and exclusion in Dom and Musahar, two mahadalit community of Bihar, established the objectives to a large extent. When analyzed separately for Dom and Musahar the results revealed that in case of Dom on 8 statements they showed marginalisation and exclusion, 5 statements no impact and on 1 statement they were undecided. While in case of Musahar they showed marginalisation and exclusion on 6 statements, no impact on 7 statements and undecided on 1 statement. This way Dom had shown comparatively greater impact of marginalisation and exclusion as compared to Musahar caste. Marginalisationwas evident as they did not get equal opportunity for work in village, Government subsidy for housing, subsidy for business, equal social status etc. whereas they did not see marginalisationpartially or fully in children attending school and their social handling, untouchability, health facilities etc.

\section{Discussion:}

To quote Nancy Frazer, "Bivalent collectivities, in sum, may suffer both socioeconomic maldistribution and cultural misrecognition in forms where neither of these injustices is an indirect effect of the other, but where both are primary and co-original. In their case, neither the politics of redistribution alone nor the politics of recognition alone will suffice. Bivalent collectivities need both" (Fraser 1996). Caste, in this case Dom and Musahar, seem to be placed 
Towards Excellence: An Indexed, Refereed \& Peer Reviewed Journal of Higher Education / Dr. Amrita Shilpi/ Page 13-35

in the center of the conceptual spectrum of misrecognition and misdistribution. Their position is rooted in the economic structure and the status order of the society simultaneously.

The perception of marginalisation and exclusion can be sited to both political economy and culture simultaneously. Members of marginalized communities have been, and are, systematically denied dignity, self-esteem and recognition, either as persons or on account of their way of life and culture. Such processes of denial and disrespect extend into their everyday life and practices and spill over into the lives of children and their families seeking out, or having interventions imposed upon them (Garret 2010). Gordon et al (2000) propose four core areas of exclusion. They are poverty or exclusion from sufficient income or resources; exclusion from labour market; exclusion from housing and important services; and exclusion from social and community relations. As reported in the study, job opportunities are available but they felt excluded in terms of such opportunities available to them. As a matter of distribution, their share of the benefits is discriminatorily small. Job opportunities available are menial and exploitable that do not go a long way to address the range of social suffering and stigmatization. Dom felt marginalized when asked about the job opportunities available to them. They have traditionally been basket weavers rigorous labour was not their strength. Members of these groups show high levels of unemployment and poverty and overrepresentation in low-paying menial work.

The struggle for survival relies mostly on the availability of basic needs. Hospital is available but the quality of medical facilities (availability of doctor, nursing staff, medicines) is debatable. School is available but there is no mixing up of children of upper cases. In addition to it, the quality of education is arguable. Mid day meal is available but no one questions the nutrition value. Can't this be a situation where the economic structure has produced community specific forms of maldistribution?

Not only this but, there are certain kinds of suffering and deprivation that invariably have a recognition element. Caste still forms a pertinent aspect of recognition in rural India. Ascribed status of being a low caste person brings with it a multitude of shortcomings affecting life chances in areas like education, occupation, and income. Low castes had lower average educational achievement, aggravated both by structural impediments and by the internalization of low self-worth (Hoff and Pandey 2004). Recognition of the participation of the depressed castes in the society has been questioned recurrently (Kumar 2005). The fact that they have contributed throughout in the smooth running of the society, economy and polity, has never been 
Towards Excellence: An Indexed, Refereed \& Peer Reviewed Journal of Higher Education / Dr. Amrita Shilpi/ Page 13-35

recognized constructively. The contribution made by woman as a midwife serving and assisting millions of women children has never been evaluated neither as a moral contribution to humanity nor as a part of the indigenous knowledge system. The role of a grave-digger or Dom who helps light the funeral pyre, or people who toil as landless labourers in fields and in industries has never been chronicled. Their labour blacked out, even the technology and aesthetics involved in their labour was never ever taken cognizance of. He concludes that the denial of recognition of the contributions made by the depressed castes for the development of society has a direct effect on their stigmatization. They are projected as unclean, drunkard, devoid of burden, untrustworthy and so on. Discrimination in housing, employment, and health care, the non-recognition of their cultural production, harassment and ridicule in everyday life and exclusion or marginalisationin public spheres are some of the examples of inherited social inequalities. Inherited social inequalities, cultural differences, economic disparities, inaccessibility to the welfare provisions such as education, health etc., have been some social conditions that have undermined the exercise of equal citizenship (Jayal 1999). For Frazer these are quintessential harms of misrecognition that can be remedied only by recognition. Prevailing over such vulnerable existence requires both redistribution and recognition. Neither alone will suffice (Fraser 1996).

\section{Conclusion}

Interestingly, the latent energy of our social system is making the entire perception of marginalisation and exclusion undergo a phase transition. There is no apparent change in the beliefs and practices in general but perception of marginalisation and exclusion is changing, at least from the responses of the section studied here. From Fraser's perspective the need is to go beyond the 'affirmative strategies' for 'redressing injustice which aim to correct discriminatory outcomes of social arrangements without changing the underlying social structures than generate them' (Fraser 2003). What is required, she insists, are 'transformative strategies' that seek to 'correct unjust outcomes precisely by restructuring the underlying generative framework' (Fraser 2003). This would intervention both from the perspective of economic redistribution and sociocultural transformation.

The paper tries to establish that marginalisation and exclusion of Dom and Musahar communities is socio-economic (ingrained in the economic structure of society) and is also rooted in cultural, social patterns of representation, interpretation, and communication for e.g. cultural domination, non-recognition and disrespect. Mitigation is possible through economic restructuring along with 
Towards Excellence: An Indexed, Refereed \& Peer Reviewed Journal of Higher Education / Dr. Amrita Shilpi/ Page 13-35

a cultural or symbolic change in ways that would change the social identity of concerned groups. In addition to economic developmental activities efforts might be directed to increase motivation level to achieve indices of quality of life through proper management of aspirations and achievements. Dom and Musahar communities are defined economically by a distinctive relation to the market or the means of production for e.g 'low-paid menial labourers', or 'unwaged labour', who are disadvantaged in employment and also the relations of recognition, for e.g. 'the low-status ethnic group' having lesser respect, esteem, and prestige. Both the castes need improvement in quality of life. Quality of life, a multi dimensional concept, includes material living status (for example, income, consumption and wealth, health status, education, social interactions, political consciousness) and physical and psychological well being. Suitable steps need to be intensified to improve existing objective conditions and capabilities through administrative and socially productive measures.

\section{Recommendation:}

The results of the present study suggest that marginalisation and exclusion in Dom and Musahar, both belonging to Mahadalit Community of Bihar, has not been done away with to the level of proper social functioning. New forms of discrimination have evolved which needs to be looked into from contemporary approach. These findings are even more relevant in the sense that the responses have been that of the affected people which might be termed as felt one and not judged one by others.

Dom and Musahar castes feel that the process of their integration in the society has begun but a lot remains to be done. Both the castes Dom and/or Musahar did perceive marginalisation and exclusion partially or fully on some indices like social status, opportunity in developmental schemes, untouchability, support for business, subsidies for housing, welfare schemes of the Government etc. but on some other indices like availability of schools, mid-day meals, health facilities, care in health centres / hospitals, social treatment in public places majority did not feel excluded.

\section{Acknowledgement}

The data and discussion of this paper is based on the research entitled "Social Psychology of Marginalisation and Exclusion: A Study of Dom and Musahar Communities of Bihar" (2016-18). The research was fully funded by Indian Council of Social Science Research, New Delhi under 
Towards Excellence: An Indexed, Refereed \& Peer Reviewed Journal of Higher Education / Dr. Amrita Shilpi/ Page 13-35

its Sponsored Research Project. The author, who was co PI, extends her sincere thanks to ICSSR for its financial support and other necessary assistance towards the completion of the project. She also expresses her gratitude to Prof G.P Thakur (PI) and Prof R.N Rai (co PI) for their support and guidance. 
Towards Excellence: An Indexed, Refereed \& Peer Reviewed Journal of Higher Education / Dr. Amrita Shilpi/ Page 13-35

\section{References:}

Bihar Scheduled Areas Regulation Act 1969 accessed on http://www.jharkhand.gov.in/documents/10179/5676204/THEper cent20BIHARper cent20SCHEDULEDper cent20AREASper cent20REGULATIONper cent2Cper cent201969

Briggs, GW. 1953. The Doms and their near relations. Mysore: The Wesley Press and Publication House.

Clarke, GR. 1903 . The Outcasts, Being a Brief History of the Maghaya Doms. Thacker, Spink \& Co

Crook, W. 1975.The Tribes and Castes of the North-Western India. Vol I-IV., Delhi: Cosmos.

Deshpande, A 2000. Does Caste Still Define Disparity? A Look at Inequality in Kerala India. The American Economic Review, 90 (2): 322-25.

Fraser N 2000 'Rethinking recognition', New Left Review.3

Fraser, N, A. Honneth 2003 'Introduction: Redistribution or recognition?' in Fraser, N. and Honneth, A. (eds), Redistribution or Recognition? Verso: London and New York.

Fraser, N. 2003 'Social Justice in the Age of Identity Politics: Redistribution, Recognition and Participation'. In N. Fraser and A. Honneth, Redistribution or Recognition? A PoliticalPhilosophical Exchange. Verso: London and New York.

Fuch, S 1981. At the Bottom of Indian Society. Delhi: Munshiram Manoharlal Publishers.

Garrett, P M 2010. Recognizing the Limitations of the Political Theory of Recognition: Axel Honneth, Nancy Fraser and Social Work. The British Journal of Social Work, Vol. 40, No. 5 (JULY), p1523

Ghurey, G.S 1957. India: Caste and Class in India. Bombay: Popular Book Depot.

Hoff, K \&Pandey, P 2004. Belief systems and durable inequalities: An experimental investigation of Indian caste. World Bank Policy Research Working Paper No. 3351.

Jayal,NG 1999. Democracy and the State Welfare, Secularism and Development in Contemporary India. Delhi: Oxford University Press.

Rousseau JJ. 1996. Discourse on the Origin and Foundations of Inequality Among Men in The Discourses and Other Early Political Writings. Ed. Victor Gourevitch. Cambridge: Cambridge University Press.

Jodhka, S, Newman K 2007. In the Name of Globalisation. Economic and Political Weekly. Vol. 42, Issue No. 41, 13 Oct.

Kumar, V 2005. Situating Dalits in Indian Sociology. Sociological Bulletin, Vol. 54, No. 3, Special Issue on South Asia: The State of Sociology: Issues of Relevance and Rigour (September - December).p 514-532

Kumari, A 2018. Adjustment Problems of Mahadalit and Dalit +2 Students. International Journal Recent Sci Res. 9(3), pp.24929-24932.DOI: http://dx.doi.org/10.24327/ijrsr.2018.0903 .1755 
Towards Excellence: An Indexed, Refereed \& Peer Reviewed Journal of Higher Education / Dr. Amrita Shilpi/ Page 13-35

Lister, R 2004. A politics of recognition and respect: Involving people with experience of poverty in decision-making that affects their lives. In Andersen, J. \& Siim, B. (Eds.), The Politics of Inclusion and Empowerment. New York, NY: Palgrave

Mishra, PK 1912. Harijans in Hindu and Tribal Social Structures. New Delhi: Discovery Publication House.

Mukul 1999. The Untouchable Present: Everyday Life of Musahars in North Bihar. Economic and Political Weekly. Vol. 34, No. 49 (Dec. 4-10). pp. 3465-3470

Nancy F 1996. Social Justice in the Age of Identity Politics: Redistribution, Recognition and Participation. The Tanner Lecture on Human Values. Delivered at Stanford University April 30-May 2. pp 7-10.

Philipose, P 2013. Land, Dignity, Rights Awakening of Eastern India's Musahars. Critical Stories of Change 2. Action Aid. New Delhi.

Singh, D P 2016. Socio-Demographic Condition of One of the Most Marginalised Caste in Northern India. Demography India Vol.45, Issue: 1\&2. pp.117-130

Thorat S, Newman K 2007. Caste and Economic Discrimination: Causes, Consequences and Remedies. Economic and Political Weekly. vol. 42. Issue 41 . October 13.

Tilak,JBG 1980. Education and Labour Market Discrimination. Indian Journal of Industrial Relations, Vol. 16, No. 1 (Jul.). pp 95-114

\section{List of Tables}

TABLE - 1

Earning opportunities provided by Panchayat

\begin{tabular}{|c|c|c|c|c|c|c|c|}
\hline Caste & Impact & Frequency & $\begin{array}{l}\text { per } \\
\text { cent }\end{array}$ & $\begin{array}{l}\text { Expected } \\
\text { frequency }\end{array}$ & $\mathbf{X}^{2}$ & df & $\mathbf{P}$ \\
\hline \multirow{3}{*}{ Dom } & $\begin{array}{c}\text { No } \\
\text { Marginalization }\end{array}$ & 171 & 87.2 & 98 & \multirow{3}{*}{108.755} & \multirow[t]{3}{*}{1} & \multirow[t]{3}{*}{.01} \\
\hline & Marginalization & 25 & 12.8 & 98 & & & \\
\hline & Total & 196 & 100.0 & & & & \\
\hline \multirow{3}{*}{ Musahar } & $\begin{array}{c}\text { No } \\
\text { Marginalization }\end{array}$ & 428 & 97.5 & 219.5 & \multirow{3}{*}{396.103} & \multirow[t]{3}{*}{1} & \multirow[t]{3}{*}{.01} \\
\hline & Marginalization & 11 & 2.5 & 219.5 & & & \\
\hline & Total & 439 & 100 & & & & \\
\hline
\end{tabular}


Towards Excellence: An Indexed, Refereed \& Peer Reviewed Journal of Higher Education / Dr. Amrita Shilpi/ Page 13-35

TABLE -2

Fair chances of opportunity of work in comparison to others in Panchayat

\begin{tabular}{|c|c|c|c|c|c|c|c|}
\hline Castes & Impact & Frequency & $\begin{array}{l}\text { per } \\
\text { cent }\end{array}$ & $\begin{array}{l}\text { Expected } \\
\text { frequenc } \\
y\end{array}$ & $X^{2}$ & df & $\mathbf{P}$ \\
\hline \multirow{3}{*}{ Dom } & Marginalization & 171 & 87.2 & & & & \\
\hline & $\begin{array}{c}\text { Missing } \\
\text { (Not Applicable) }\end{array}$ & 25 & 12.8 & & & & \\
\hline & Total & 196 & 100.0 & & & & \\
\hline \multirow{3}{*}{ Musahar } & $\begin{array}{c}\text { No } \\
\text { Marginalization }\end{array}$ & 35 & 8.0 & 218 & \multirow[b]{2}{*}{$\begin{array}{c}307.23 \\
9\end{array}$} & \multirow[b]{2}{*}{1} & \multirow[b]{2}{*}{.01} \\
\hline & $\begin{array}{l}\text { Marginalisation } \\
\text { (Not responded) }\end{array}$ & $\begin{array}{c}401 \\
3 \\
\end{array}$ & $\begin{array}{r}91.3 \\
0.7 \\
\end{array}$ & 218 & & & \\
\hline & Total & 439 & 100.0 & & & & \\
\hline
\end{tabular}

TABLE- 3

Information about Government schemes

\begin{tabular}{|c|c|c|c|c|c|c|c|}
\hline Caste & Impact & $\begin{array}{l}\text { Fre } \\
\text { per }\end{array}$ & & $\begin{array}{l}\text { expected } \\
\text { frequency }\end{array}$ & $\begin{array}{l}\text { Chi } \\
\text { Square }\end{array}$ & df & $\mathbf{P}$ \\
\hline \multirow{3}{*}{ Dom } & $\begin{array}{c}\text { No } \\
\text { Marginalization }\end{array}$ & & 3.1 & 98.0 & \multirow{3}{*}{172.735} & \multirow{3}{*}{1} & \multirow{3}{*}{.01} \\
\hline & Marginalization & 190 & 96.9 & 98.0 & & & \\
\hline & Total & 196 & 100 & & & & \\
\hline \multirow[t]{3}{*}{ Musahar } & $\begin{array}{c}\text { No } \\
\text { Marginalization }\end{array}$ & & 11.6 & 219.5 & \multirow{3}{*}{258.699} & \multirow{3}{*}{1} & \multirow{3}{*}{.01} \\
\hline & Marginalization & 388 & 88.4 & 219.5 & & & \\
\hline & Total & 439 & 100 & & & & \\
\hline
\end{tabular}

TABLE- 4

Government subsidy for house construction

\begin{tabular}{|c|c|c|c|c|c|c|}
\hline Caste & Impact & $\begin{array}{l}\text { Frequency } \\
\text { per cent }\end{array}$ & $\begin{array}{l}\text { Expected } \\
\text { frequency }\end{array}$ & $\begin{array}{c}\text { Chi } \\
\text { Squar } \\
\text { e } \\
\end{array}$ & $\begin{array}{l}\text { D } \\
\text { f }\end{array}$ & $\mathbf{P}$ \\
\hline \multirow{3}{*}{ Dom } & $\begin{array}{c}\text { No } \\
\text { Marginalization }\end{array}$ & $\begin{array}{l}51 \\
26\end{array}$ & 98 & \multirow{3}{*}{$\begin{array}{l}45.08 \\
2\end{array}$} & \multirow{3}{*}{1} & \multirow{3}{*}{.01} \\
\hline & Marginalization & $\begin{array}{l}145 \\
74\end{array}$ & 98 & & & \\
\hline & Total & 196 & & & & \\
\hline
\end{tabular}


Towards Excellence: An Indexed, Refereed \& Peer Reviewed Journal of Higher Education / Dr. Amrita Shilpi/ Page 13-35

\begin{tabular}{|c|c|c|c|c|c|c|}
\hline \multirow[t]{3}{*}{ Musahar } & $\begin{array}{c}\text { No } \\
\text { Marginalization }\end{array}$ & $\begin{array}{l}143 \\
32.6\end{array}$ & 219.5 & \multirow{3}{*}{$\begin{array}{l}53.32 \\
3\end{array}$} & \multirow[t]{3}{*}{1} & \multirow[t]{3}{*}{.01} \\
\hline & Marginalization & $\begin{array}{l}296 \\
67.4\end{array}$ & 219.5 & & & \\
\hline & Total & 439 & & & & \\
\hline
\end{tabular}

TABLE-5

Government subsidy for business

\begin{tabular}{|c|c|c|c|c|c|c|c|}
\hline Caste & Impact & $\begin{array}{l}\text { Freq } \\
\text { per }\end{array}$ & & $\begin{array}{l}\text { Expected } \\
\text { frequency }\end{array}$ & $\begin{array}{l}\text { Chi } \\
\text { Square }\end{array}$ & df & $\mathbf{P}$ \\
\hline \multirow[t]{3}{*}{ Dom } & $\begin{array}{c}\text { No } \\
\text { Marginalization }\end{array}$ & & 1.0 & 98.0 & \multirow{3}{*}{188.082} & \multirow{3}{*}{1} & \multirow{3}{*}{.01} \\
\hline & Marginalization & 194 & 99.0 & 98.0 & & & \\
\hline & Total & 196 & 100.0 & & & & \\
\hline \multirow[t]{3}{*}{ Musahar } & $\begin{array}{c}\text { No } \\
\text { Marginalization }\end{array}$ & & 3.6 & 219.5 & \multirow{3}{*}{377.333} & \multirow{3}{*}{1} & \multirow{3}{*}{.01} \\
\hline & Marginalization & 423 & 96.4 & 219.5 & & & \\
\hline & Total & 439 & 100.0 & & & & \\
\hline
\end{tabular}

TABLE -6

Children going to school

\begin{tabular}{|c|c|c|c|c|c|c|c|}
\hline Caste & Impact & $\begin{array}{l}\text { Fre } \\
\text { per }\end{array}$ & & $\begin{array}{l}\text { Expected } \\
\text { frequency }\end{array}$ & $\begin{array}{l}\text { Chi } \\
\text { Square }\end{array}$ & df & $\mathbf{P}$ \\
\hline \multirow{3}{*}{ Dom } & $\begin{array}{c}\text { No } \\
\text { Marginalization }\end{array}$ & 123 & 62.8 & 98 & \multirow{3}{*}{12.755} & \multirow{3}{*}{1} & \multirow{3}{*}{.01} \\
\hline & Marginalization & 73 & 37.2 & 98 & & & \\
\hline & Total & 196 & 100 & & & & \\
\hline \multirow{3}{*}{ Musahar } & $\begin{array}{c}\text { No } \\
\text { Marginalization }\end{array}$ & 366 & 83.4 & 219.5 & \multirow{3}{*}{195.556} & \multirow{3}{*}{1} & \multirow{3}{*}{.01} \\
\hline & Marginalization & 73 & 16.6 & 219.5 & & & \\
\hline & Total & 439 & 100 & & & & \\
\hline
\end{tabular}


Towards Excellence: An Indexed, Refereed \& Peer Reviewed Journal of Higher Education / Dr. Amrita Shilpi/ Page 13-35

TABLE -7

Treatment in mid-day meal in schools

\begin{tabular}{|c|c|c|c|c|c|c|c|}
\hline Caste & Impact & $\begin{array}{l}\text { freq } \\
\text { per }\end{array}$ & & $\begin{array}{l}\text { expected } \\
\text { frequency }\end{array}$ & $\begin{array}{l}\text { Chi } \\
\text { Square }\end{array}$ & df & p. \\
\hline \multirow{3}{*}{ Dom } & No Marginalization & & 38.8 & 67.5 & \multirow{2}{*}{2.141} & \multirow{2}{*}{1} & \multirow{2}{*}{ NS } \\
\hline & Marginalization & 59 & 30.1 & 67.5 & & & \\
\hline & Total & 135 & 68.9 & & & & \\
\hline \multirow{3}{*}{ Musahar } & No Marginalization & 287 & 65.4 & 203.0 & \multirow[b]{2}{*}{69.517} & \multirow[b]{2}{*}{1} & \multirow[b]{2}{*}{.01} \\
\hline & Marginalization & 119 & 27.1 & 203.0 & & & \\
\hline & Total & 406 & 92.5 & & & & \\
\hline
\end{tabular}

TABLE- 8

Availability of Utensil for mid- day meal provided by the school

\begin{tabular}{|c|c|c|c|c|c|c|c|}
\hline Caste & Impact & $\begin{array}{l}\text { Fre } \\
\text { per }\end{array}$ & & $\begin{array}{l}\text { Expected } \\
\text { frequency }\end{array}$ & $\begin{array}{l}\text { Chi } \\
\text { Square }\end{array}$ & Df & $\mathbf{P}$ \\
\hline \multirow{3}{*}{ Dom } & No Marginalization & & 23 & 67.5 & \multirow{3}{*}{15.00} & \multirow{3}{*}{1} & \multirow{3}{*}{.01} \\
\hline & Marginalization & 90 & 45.9 & 67.5 & & & \\
\hline & Total & 135 & 68.9 & & & & \\
\hline \multirow{3}{*}{ Musahar } & No Marginalization & 221 & 50.3 & 203 & \multirow{3}{*}{3.192} & \multirow{3}{*}{1} & \multirow{3}{*}{ NS } \\
\hline & Marginalization & 185 & 42.1 & 203 & & & \\
\hline & Total & 406 & 92.5 & & & & \\
\hline
\end{tabular}

TABLE-9

Getting tea on nearby tea shop in shop's glass/cup

\begin{tabular}{|c|c|l|l|l|l|l|}
\hline Caste & \multicolumn{1}{|c|}{ Impact } & $\begin{array}{c}\text { Frequency } \\
\text { per cent }\end{array}$ & $\begin{array}{c}\text { expected } \\
\text { frequency }\end{array}$ & $\begin{array}{c}\text { Chi } \\
\text { Square }\end{array}$ & df & P \\
\hline & $\begin{array}{c}\text { No } \\
\text { Marginalization }\end{array}$ & $\begin{array}{l}163 \\
83.2\end{array}$ & 98.0 & & & \\
\hline
\end{tabular}


Towards Excellence: An Indexed, Refereed \& Peer Reviewed Journal of Higher Education / Dr. Amrita Shilpi/ Page 13-35

\begin{tabular}{|c|c|c|c|c|c|c|}
\hline \multirow[t]{3}{*}{ Dom } & & & & \multirow{3}{*}{86.224} & \multirow{3}{*}{1} & \multirow{3}{*}{.01} \\
\hline & Marginalization & $\begin{array}{l}33 \\
16.8\end{array}$ & 98.0 & & & \\
\hline & Total & $196 \quad 100$ & & & & \\
\hline \multirow{3}{*}{ Musahar } & $\begin{array}{c}\text { No } \\
\text { Marginalization }\end{array}$ & $\begin{array}{l}418 \\
95.2\end{array}$ & 219.5 & \multirow{3}{*}{359.018} & \multirow{3}{*}{1} & \multirow{3}{*}{01} \\
\hline & Marginalization & $\begin{array}{l}21 \\
4.8\end{array}$ & 219.5 & & & \\
\hline & Total & $\begin{array}{l}439 \\
100\end{array}$ & & & & \\
\hline
\end{tabular}

TABLE- 10

Practice of untouchability

\begin{tabular}{|c|c|cc|c|c|c|c|}
\hline Caste & Impact & \multicolumn{2}{|c|}{$\begin{array}{c}\text { Frequency } \\
\text { cent }\end{array}$} & $\begin{array}{c}\text { expected } \\
\text { frequency }\end{array}$ & $\begin{array}{c}\text { Chi } \\
\text { Square }\end{array}$ & df & P \\
\hline \multirow{3}{*}{ Dom } & No Marginalization & 120 & 61.2 & 98.0 & 9.878 & 1 & .05 \\
\cline { 2 - 9 } & Marginalization & 76 & 38.8 & 98.0 & & & \\
\cline { 2 - 9 } Musahar & No Marginalization & 143 & 32.6 & 219.5 & \multirow{2}{*}{53.323} & 1 & .01 \\
\hline
\end{tabular}

TABLE- 11

Availability of hospital in vicinity for medical emergency

\begin{tabular}{|c|c|c|c|c|c|c|}
\hline Caste & Impact & $\begin{array}{c}\text { Frequency } \\
\text { per cent }\end{array}$ & $\begin{array}{l}\text { Expected } \\
\text { frequency }\end{array}$ & $\begin{array}{c}\text { Chi } \\
\text { Square }\end{array}$ & df & $\mathbf{P}$ \\
\hline \multirow{3}{*}{ Dom } & $\begin{array}{c}\text { No } \\
\text { Marginalisation }\end{array}$ & 87 & 98.0 & \multirow{3}{*}{2.469} & \multirow{3}{*}{1} & \multirow{3}{*}{ NS } \\
\hline & Marginalization & 55.6 & 98.0 & & & \\
\hline & Total & $\begin{array}{c}196 \\
100.0\end{array}$ & & & & \\
\hline Musaha & $\begin{array}{c}\text { No } \\
\text { Marginalization }\end{array}$ & $242 \quad 55.1$ & 219.5 & 4613 & 1 & 05 \\
\hline ivitusanal & & & & & 1 & \\
\hline
\end{tabular}


Towards Excellence: An Indexed, Refereed \& Peer Reviewed Journal of Higher Education / Dr. Amrita Shilpi/ Page 13-35

TABLE- 12

Hesitation in touching body by medics while administering treatment

\begin{tabular}{|c|c|cc|c|c|c|c|}
\hline Caste & Impact & \multicolumn{2}{|c|}{$\begin{array}{c}\text { Frequency } \\
\text { per cent }\end{array}$} & $\begin{array}{c}\text { expected } \\
\text { frequency }\end{array}$ & $\begin{array}{c}\text { Chi } \\
\text { Square }\end{array}$ & df & P \\
\hline \multirow{3}{*}{ Dom } & $\begin{array}{c}\text { No } \\
\text { Marginalization }\end{array}$ & 192 & 98.0 & 98.0 & \multirow{2}{*}{180.327} & 1 & .01 \\
\cline { 2 - 9 } & Marginalization & 4 & 2.0 & 98.0 & & & \\
\cline { 2 - 9 } & Total & $\mathbf{1 9 6}$ & $\mathbf{1 0 0 . 0}$ & & & & \\
\hline \multirow{2}{*}{ Musahar } & $\begin{array}{c}\text { No } \\
\text { Marginalization }\end{array}$ & 397 & 90.4 & 219.5 & 287.073 & 1 & .01 \\
\hline
\end{tabular}

TABLE- 13

Social status in the village

\begin{tabular}{|c|c|c|c|c|c|c|c|}
\hline Caste & Impact & $\begin{array}{l}\text { Fre } \\
\text { per }\end{array}$ & & $\begin{array}{l}\text { expected } \\
\text { frequency }\end{array}$ & $\begin{array}{l}\text { Chi } \\
\text { Square }\end{array}$ & df & $\mathbf{P}$ \\
\hline \multirow[t]{3}{*}{ Dom } & $\begin{array}{c}\text { No } \\
\text { Marginalization }\end{array}$ & & 11.7 & 98.0 & \multirow[t]{3}{*}{114.796} & \multirow[t]{3}{*}{1} & \multirow[t]{3}{*}{.01} \\
\hline & Marginalization & 173 & 88.3 & 98.0 & & & \\
\hline & Total & 196 & 100.0 & & & & \\
\hline Musahar & $\begin{array}{c}\text { No } \\
\text { Marginalization }\end{array}$ & & 10.5 & 219.5 & 274.280 & 1 & .01 \\
\hline
\end{tabular}

TABLE- 14

Untouchability been eradicated from society

\begin{tabular}{|c|c|c|c|c|c|c|c|}
\hline Caste & Impact & & $\begin{array}{l}\text { ency } \\
\text { ent }\end{array}$ & $\begin{array}{l}\text { expected } \\
\text { frequency }\end{array}$ & $\begin{array}{c}\text { Chi } \\
\text { Square }\end{array}$ & Df & $\mathbf{P}$ \\
\hline \multirow[t]{3}{*}{ Dom } & $\begin{array}{c}\text { No } \\
\text { Marginalization }\end{array}$ & & 41.8 & 98 & \multirow[t]{3}{*}{5.224} & \multirow[t]{3}{*}{1} & \multirow[t]{3}{*}{.05} \\
\hline & Marginalization & 114 & 58.2 & 98 & & & \\
\hline & Total & 196 & 100.0 & & & & \\
\hline \multirow[t]{3}{*}{ Musahar } & $\begin{array}{c}\text { No } \\
\text { Marginalization }\end{array}$ & 218 & 49.7 & 219.5 & \multirow[t]{3}{*}{.021} & \multirow[t]{3}{*}{1} & \multirow[t]{3}{*}{ NS } \\
\hline & Marginalization & 221 & 50.3 & 219.5 & & & \\
\hline & Total & 439 & 100.0 & & & & \\
\hline
\end{tabular}

\section{Dr. Amrita Shilpi \\ Assistant Professor, Department of Political Science \\ Lakshmibai College, New Delhi \\ Email id : amritashilpi7@gmail.com}

